\title{
Appendix: Previous research on the single case studies
}

\section{PREVIOUS RESEARGH ON CANDI JAGO}

The first comprehensive research on Candi Jago was undertaken by Brandes and published in his monumental monograph of 1904. In the tradition of the early archaeologists, he provides a meticulous description of the candi, together with 235 photographs of the temple and the relief panels. Krom (1923, II:95-138) dedicates a large chapter to Candi Jago with a detailed description of its architecture. ${ }^{1}$ More recent research has been conducted by Bernet Kempers (1981a) on the Kunjarakarna reliefs. O'Brien $(1988,1990,1993)$ was the first scholar to give an interpretation of the overall symbolism of Candi Jago. She proposes this temple presents a Buddhist mandala in combination with the symbolism of the Wheel of Existence. Furthermore, she places an emphasis on the function of the placement of the reliefs according to these schemata. Klokke (1993:143-7), in her analysis of the Tantri reliefs of Candi Jago, discusses and partly questions O'Brien's interpretation, judging it to be overinterpreted. ${ }^{2}$ Hunter (2000) offers a new interpretation of the Aridharma/ Angling Dharma reliefs. In a recent article, I have in particular examined the cap-figures at Candi Jago (Kieven 2008).

\section{PREVIOUS RESEARCH ON CANDI PANATARAN}

The earliest documentations of Candi Pantaran are found in the work of Raffles (1817:38-40) and Hoepermans (1913b), and in Van Kinsbergen's

Not only in the case of Candi Jago, but for all temples and sanctuaries discussed in my book, Krom (1923, II) provides invaluable references to the outcomes of prior research.

2 I agree on most points with O'Brien, but I am also cautious, as is Klokke, with regard to the comparison with rather recent Tibetan paintings. See the response by O'Brien (1995). 
beautiful photographs of the Panataran buildings in the year $1867 .^{3}$ Major investigations and restorations by the Dutch authorities were carried out in 1901 and reported by, amongst others, Brandes (1902a, 1902b), Knebel (1908a), Perquin (1915, 1916b, 1917), and De Haan (1920). Krom (1923, II:254-84) dedicates a substantial chapter to Candi Panataran, drawing upon the research completed up until that point. Van Stein Callenfels' (1924) studies on the Krishnayana reliefs on the first terrace of the Main Temple and Stutterheim's (1925) studies of the Ramayana reliefs on the base of the same temple are further important contributions to our knowledge of Panataran. ${ }^{4}$ Pannenborg-Stutterheim (1947) provides a study on the particular function of the Naga-temple. The detailed research on the Pendopo Terrace and its reliefs by Suleiman Satyawati (1978) is an invaluable source for my interpretation of these reliefs. Klokke's (1993) investigation of the Tantri reliefs on several of the Panataran buildings stands as another relevant contribution for my investigation. Her study (2000c) of the Krishnayana reliefs is a revision of Van Stein Callenfels' earlier work.

The function of Candi Panataran has evoked various opinions and discussions, for example by Stutterheim (1989:150-1), Pigeaud (1960-63, IV:163-4), and, more recently, by De Casparis and Mabbett (1992:316) and K. Hall (1996:112). Commonly this temple has been considered as the State Temple of Majapahit. So far, however, no comprehensive study of the whole temple and its overall function and meaning has been presented. ${ }^{5}$ My investigation of the cap-figures will provide a starting point for a new discussion of an overall interpretation, and I will offer a new understanding of this most important temple of the Majapahit period, an understanding which opened my eyes for the encounters with the other temples and sanctuaries researched for this book.

\footnotetext{
$3 \quad$ Hoepermans' report was based on visits in 1864-67. Van Kinsbergen's photos are kept in the photo archive of the Kern Institute in Leiden/ Netherlands. See Theuns-de Boer 2005, particularly photos nos. 246-332.

4 Both authors provided several other publications which refer to Candi Panataran. Stutterheim's original (1925) book on the Ramayana reliefs in German was later published in English (1989). Stutterheim draws upon Brandes (1909) and in particular on his photos, published in his monograph on Candi Singasari.

5 I have plans to work on a monograph of Candi Panataran in the future.
} 


\section{PREVIOUS RESEARCH ON CANDI SUROWONO}

Studies on Candi Surowono and the reliefs have been published by Van Stein Callenfels (1919, 1925b), Krom (1923, II:209-16), Galestin (1939a), and Bernet Kempers (1959:298-303). The most important question that these studies have in common concerns the unorthodox way in which the three different narrative relief series are arranged. Neither a clear pradakshina- nor a prasawya direction could be identified. Van Stein Callenfels (1925b:39) and Krom (1923, II:214), without having identified the Sri Tanjung reliefs, argue that the artists had either been wrong or very free in the arrangement of the reliefs. Galestin (1939a) also encounters problems with the order and interpretation of some of the panels, but is able to identify the Sri Tanjung reliefs. ${ }^{6}$ In a later publication, Worsley (1986) draws special attention to the deliberate selection and placement of episodes on the temple walls, with this inciting a discussion between Klokke (1995) and himself (Worsley 1996). The outcome of this discussion has provided an essential contribution to the understanding of the spatial arrangement of temple reliefs in general.

The narratives depicted on Candi Surowono - the Arjunawiwaha, Sri Tanjung, and Bubukshah and Gagak Aking - have been objects of various philological as well as arthistorical studies. The kakawin Arjunawiwaha has been translated into Dutch by Poerbatjaraka (1926b), who omits the 'erotic' scenes which he declares to be corruptions. Later, Padmapuspita (1988b) as well as Kuntara Wiryamartana (1990) provide translations of the text into Indonesian. In his edition and interpretation of the text, Kuntara Wiryamartana places a focus on the Tantric aspect. In his recent, new edition, translated into English, Robson (2008) rejects the idea of a Tantric concept in the Arjunawiwaha. I (Kieven 1994:77-97) examine in particular the aspect of asceticism in the Arjunawiwaha at Candi Surowono. The kidung Sri Tanjung has been edited and translated into Dutch by Prijono (1938). To date, there has been no further analysis of this text. Aspects of the story are discussed by Galestin (1939a) in a comparison of Sri Tanjung depictions at several temples, and by Worsley and Klokke in their investigations of Candi Surowono. ${ }^{7}$ The Bubukshah story

\footnotetext{
6 He mentions his confusion about the arrangement of the reliefs in an unpublished paper quoted in Worsley (1986:365, fn. 8).

7 Short discussions of both - Arjunawiwaha and Sri Tanjung - are also rendered in Zoetmulder 1974:234-49, 433-6.
} 
features as a subject of discussion for Van Stein Callenfels (1919:348-9) and Rassers (1959:74) with the latter focusing on the combination of Buddhist and Saiwite aspects.

\section{PREVIOUS RESEARCH ON CANDI MIRIGAMBAR}

Early research into Candi Mirigambar was undertaken by the Dutch authorities. Hoepermans (1913a:335-7) in his archaeological report from 1864-1867 refers to six temple ruins in the neighbourhood, most of them having almost fallen apart completely and today not extant any more. They were made of brick, except one, which was made of andesite. ${ }^{8}$ Knebel (1908b:220-2) mentions earlier that one relief panel was missing. Perquin (1916a:81-2, 1916b:140-4) was the first to give a description of the relief panels in his report on the restoration, from 1915 to 1916 , by the Dutch Archaeological Service. A few panels were documented in photographs. ${ }^{9}$ Krom (1923, II:334-9) presents a summary of the research completed up until that point and also provides a more detailed description of the panels. Klokke (1993:80) discusses some remaining animal reliefs on the upper foot of the temple.

\section{PREVIOUS RESEARCH ON THE SANCTUARIES ON MOUNT PENANGGUNGAN: CANDI KENDALISODO, CANDI YUDHA, AND THE PANJI STATUE FROM CANDI SELOKELIR}

In 1914 an initial exploration of the mountain was undertaken under Dutch authority, documented in a few short reports (O.V. 1914, 1915). Krom (1923, II:398-405) only dedicated a few notes on Penanggungan, since most of the sites on the mountain had not been explored yet. However he gives a more lengthy description of the findings at Candi Selokelir. In the following years, suggestions by the local people were taken up for further explorations. Stutterheim (1936a, 1938) climbed Mount Penanggungan together with A. Gall and reported on their interesting findings. In many of his later works Stutterheim adds and

\footnotetext{
8 One of the brick temples which contained some remains of stone carvings was referred to as 'Candi Tuban' (Knebel 1908b:222; Perquin 1916b:145-6).

9 OD-photos are available in the Kern Institute in Leiden.
} 
discusses information on the sites and the architectural remains from Mount Penanggungan. In particular, he discusses the Panji sculpture from Selokelir (Stutterheim 1936b) and focuses on the Bhima depictions (Stutterheim 1935a, 1940). Candi Jolotundo, the oldest sanctuary on the foot of the mountain, has drawn the attention of Stutterheim (1937a) and Bosch $(1945,1961,1965)$. A most valuable inventory of all 81 sites is provided by Van Romondt (1951), who gives descriptions of the sanctuaries and remains based on his explorations on Mount Penanggungan in the years 1936, 1937, and $1940 .{ }^{10}$ I follow his numeration of the sites in Roman numbers. Terwen-de Loos (1971) provides an interpretation of the relief depictions at Candi Kendalisodo. A short report on an exploration on the mountain is provided by Soedjono (1976). A more recent, unfortunately unpublished, MA-thesis by Agus A. Munandar (1990b) discusses the religious function of the sanctuaries, particularly the hermitages, on Mount Penanggungan during the fourteenth and fifteenth century. I (Kieven 1997, 2000) gave interpretations of the sanctuary of Candi Kendalisodo, which I further develop in Chapter $\mathrm{X}$. My discussion of water and ancestor cults in connection with Mount Penanggungan in Chapter IV provides basic knowledge for the understanding and interpretation of the sanctuaries.

1o Van Romondt also provides a complete set of references to existing publications for each site. 